ISSN : 2722-7820 (Online)

Point of View Research Accounting and Auditing

https://journal.accountingpointofview.id/index.php/povraa

\title{
Influences of tax sanctions, taxpayers awareness and social norms on motivation to meet tax obligation
}

\author{
Dendy Heryanto $†$, Mursalim2, Darwis Lannai3
}

Universitas Muslim Indonesia, Urip Sumohardjo KM.5, Makassar, 90231, South Sulawesi, Indonesia

\begin{tabular}{|c|c|}
\hline Submission Info : & Abstract \\
\hline $\begin{array}{r}\text { Editor : Iqra Allamal Insan } \\
\text { Received 24 Juny } 2020 \\
\text { Accepted 25 Juny } 2020 \\
\text { Available online 27 Juny } 2020\end{array}$ & $\begin{array}{l}\text { This research is done with the aim to analyze tax sanctions, taxpayer's } \\
\text { awareness and social norms to meet tax obligation in the KPP Pratama } \\
\text { South Makassar. The Research methods used in this study are descriptive } \\
\text { analysis double regression analysis with a total sample of } 79 \text { respondence. }\end{array}$ \\
\hline $\begin{array}{r}\text { Keyword : } \\
\text { Taxation Sanction } \\
\text { Taxpayers awareness } \\
\text { Social Norms } \\
\text { Motivation } \\
\text { Tax Obligation } \\
\end{array}$ & $\begin{array}{l}\text { were positive and significant for the taxpayer's motivation to fulfill its tax } \\
\text { obligation at KPP Pratama South Makassar. }\end{array}$ \\
\hline $\begin{array}{r}\text { Email : } \\
\text { dendy@gmail.com } \\
\text { mursalim@umi.ac.id } \\
\text { darwis.lannai@umi.ac.id }\end{array}$ & $\begin{array}{l}(c) \text { EY } \\
\text { This is an open access article under the CC BY } 4.0 \text { International License } \\
\text { (C) Point of View Research Accounting (2020) }\end{array}$ \\
\hline
\end{tabular}

\section{Introduction}

The study focuses on the level of adherence taxpayers and its relation to thrust by extrinsic motivation such as prevention, tax policy, and the role of intrinsic motivation such as moral responsibilities, norms, guilt and shame. Theory Tax Compliance expressed by Becker, (1968), Allingham \& sandmo (1972) focuses solely on the prediction of compliance based on the probability of audits or fines. This is very contrasting because empirically tax compliance is a strategic issue of the modern tax system although the audit probability is very low and the fines are low. The literature proposes three ways to solve this puzzle obedience (Sandmo, 2005).

If the tax levy is done thinking at the normative level, then the thing that arises is a negative stigma and unfavorable government position. Therefore, in the need of a philosophical level so that taxes are not identical to something frightening from time to time. Contradictory thinking normative towards the philosophical is a challenge of how to embed such things for all parties. It is not easy to do because it has been happening since hundreds of years ago. Even George Washington already reminded no taxes can be devised which are not more or less inconvenient and unpleasant. The phrase freely means that a levy with a tax name will never be comfortable and enjoyable, even with reason for the state's acceptance. However, according to Chung \& Trivedi 
(2003) in his research The Effect of Friendly persuasion and Gender on Tax Compliance Behavior suggests that friendly persuasions, in different precautions such as tax checks and tax sanctions that are not reported, are cost effective and likely to increase taxpayer compliance. Chung \& Trivedi (2003) findings inspire a pattern of approach in taxation called social norms, such as Cialdini and trost (1998), in research that found that personal norms became very significant with taxpayer compliance, and a taxpayer's motivation to pay tax revenues.

In this case Doerrenberg \& Peichl (2017) suggest that the public will be likely to participate when there is a reciprocation from the government in the form of facilities that are enjoyed publicly. Hallsworth et al. (2017), suggesting that reciprocation in this context means that the motivation to comply with taxes depends on the perceived service and quality of the country/government received by the citizens in return for their tax payments (this is also related to the concept of conditional cooperation (Frey \& Meier, 2004). In compliance studies and intrinsic motivation such as, (Slemrod et al., 2001; Kleven et al., 2011; Castro \& Scartascini, 2015; Pomeranz 2015; Dwenger et al., 2016; Boyer et al., 2016; Hallsworth et al., 2017; Bott et al., 2017; Drago et al., 2017), concluded that the anatomy of taxpayers ' behavior is related to social norms personally in the context of different moral behaviors, in fulfilling taxation obligations. Luttmer \& Singhal (2014), Doerrenberg \& peichl (2017) argued that moral tax is indeed an important component of tax compliance decisions, although law enforcement is the primary driver of compliance.

Research Jackson \& Milliron, (1986) Alm, (2012) showed that the factors influencing tax compliance include the probability of tax audits and confidence levels, trust in government justice and tax officers, and many cultural and normative factors. Subsequently, Torgler, B. (2007) said that many taxpayers are only tax registrants, but are inhibited as compliant taxpayers. In terms of the compliance ratio of annual SPT tax year 2017 until 31 December 2018, Kanwil DJP Sulselbartra has an achievement of 91.68\% or 602,510 SPT of target 657,200 SPT. While in terms of tax receivables, Kanwil DJP Sulselbartra has a tax receivable amount of Rp $1,352 \mathrm{M}$ per 31 December 2018, or $10.85 \%$.

Based on this, the enforcement of law that is carried out especially in the criminal act in the field of taxation is important in order to fulfill the sense of justice in the community and the legal certainty itself. But as it is known that the regulation related to criminal acts in the taxation field is the Re medium ultimum (last attempt) when the administrative sanction which is a major sanction is deemed not to be able to sanction sufficient sanctions against taxpayers who are shown to be unlawful, breach or criminal in the tax field. The reason for the administration of such sanctions is in relation to the state acceptance recovery efforts. It can be seen clearly from the provisions of article 44B of the KUP law which emphasizes the aspect of payment of money in lieu of criminal sanctions. Article 44B of the KUP law states that for the benefit of State acceptance, at the request of the Minister of Finance, the Attorney General may terminate the criminal investigation in the longest taxation field within the period of six months from the date of the request letter.

Michael Doran (2009) in his writing Tax Penalties and Tax Compliance suggests that sanctions such as penalties or fines or criminal penalties constitute the promotion of tax compliance. Punishment reform requires an understanding of what motivates taxpayers to pay their taxes. Furthermore the Redae, (2016) and Togler (2013) payers generally pay their taxes, because they are motivated by external and internal factors. Many factors influence a taxpayer's motivation to promote state compliance and acceptance. These factors include tax sanctions, taxpayer awareness, and social norms. Mutia (2014) found that taxation sanctions positively affect taxpayer compliance, taxation awareness of significant positive effect on taxpayer compliance, the fissure service has a significant positive impact on taxpayer compliance, the level of understanding has a significant positive effect on taxpayers ' compliance.

Cahyonowati et al., (2012) In his research found that there was an interaction between a fine tax variable and an ethics in influencing tax compliance. However, there is no empirical evidence of interaction between tax checks and ethics in influencing tax compliance. Tryana A.M. Tiraada (2013) finds' that, the higher the tax sanctions are given, the higher the taxpayer compliance with private persons in KPP Pratama Bandung Bojonegara.

It feels very ironic, in the tax discourse in any country in the world, the ending of tax is how to make taxpayers be obedient, and especially if that compliance arises voluntarily. Therefore, from any angle the tax was discussed, it ended in obedience, because the obligatory obedient were those who obeyed his Lord's teachings, his so-called gods. Annual SPT Compliance ratio of tax year 2017 until 31 December 2018, Kanwil 
DJP Sulselbartra has an achievement of $91.68 \%$ or 602,510 SPT of target 657,200 SPT. While in terms of tax receivables, KANWIL DJP Sulselbartra has a tax receivable amount of Rp 1,352 M per 31 December 2018, or $10.85 \%$. This is certainly still far from the expectation of acceptance and certainly highly associated with the awareness and normative principles. When people have awareness then paying taxes will be made voluntarily instead of compulsion. This phenomenon is related to social norms. Social norms are similar to the law, only less formal. The standards expected are not objectively recorded, and their enforcement is also informal, usually through social penalties from internal groups and communities.

The tax awareness factor has been proven to affect the successful acceptance of taxation (Suhardito, 1999). Taxpayer awareness is a sense that arises from within the taxpayer's obligation to pay the tax in sincerity without any element of compulsion. Taxpayer awareness is a logical consequence for taxpayers so that they willingly contribute funds to the implementation of taxation functions (Boediono, 1996). Low public awareness is often one of the most common causes of tax potential that cannot be netted (Soemarso, 1998). Learche, (1980) also suggested that taxation awareness is often an obstacle in the tax collection issues of the community. (Nugroho, 2006). A taxpayer with a low awareness will be inclined not to carry out its tax obligations or violate any applicable tax regulations.

This theory is the most relevant theory to explain how an idealized country can be formed. Because this theory explains the acquisition of sovereignty and legitimacy of the people by a country obtained from the agreement or agreement between the ruler and the master, where the master handed over some rights he had to be governed by the ruler in order to the creation of a country that is desirable. The theory of social contracts emerged and grew heavily influenced by the developments that existed in the age of Enlightenment where at this time was characterized by the emergence of rationalism and humanism of human thought that this teaching is a human- With the emergence of such thoughts, marking began the emergence of consciousness that man is a source of power that requires that the old man has the desire to create, manage and have a strong social political life and the idea is still strongly preserved to the present.

The relevance of the use of this theory is based on the assumption that the taxpayer will only obey the tax rules if there is a high probability that they will be examined and if the tax fine is higher (Allingham \& Sandmo, 1972). However, the examination policy and the tax fines sometimes have contradictory effects as expected (Holler et al., 2008). In addition, there may be variables other than economical-rational variables (such as threats of examination and fines) such as ethics, level of confidence in the legal and taxation systems, and religiosity that affects the tax behavior (Holler et al., 2008).

Another opinion, Hanno \& Violette (1996) stated that the decision to obey or disobey the tax rules was a cognitive behavior that was in individual control. In making a tax compliance decision, taxpayers base their attitudes on compliance that develops at all times through the acquisition of confidence (beliefs) of the output (outcomes) of compliance and evaluation of the outcomes. Some research suggests that increased likelihood of high tax checks and fines will be able to increase tax compliance (Witte \& Woodbury, 1985; Beck et al., 1991). Tax compliance will decline if taxpayers perceive tax checks to be a little because they believe they will continue to be fraudulent. This study considers variables for awareness and tax sanctions as a factor that can increase the taxpayer's motivation in fulfilling its exposure obligations. The reason for the use of the theory used in this research is that the goal of granting tax sanctions is to test the fulfillment of the taxpayer's tax obligations (compliance), and other purposes in order to enforce the provisions of taxation legislation.

The moral reasoning theory described by Kohlbeerg, (1969), is one of the important theoretical alternatives for explaining taxpayer compliance issues. According to this theory, there is a degree of moral development: in Pre-conventional levels, the motivation for moral decisions comes from fear of punishment (Stage 1), or from self-interest, such as fulfilling self-need (phase 2), at conventional level, the influence of moral decisions comes from social groups so that individuals act for fun (Stage 3), or adhering to social norms, laws, religions, rules-based moral reasoning (step 4, last on the post level conventional, individuals make decisions based on the concepts of justice such as individual rights and socially accepted standards or phases (5) Principles of universal ethics such as individual consciousness (stage 6). According to the Theory of Kohlberg (1969), it is said that individuals make moral (moral judgment) considerations using a thriving concept of justice like human beings.

The tax evasion approach Model by Allingham \& Sandmo (1972) uses the expected utility concept to 
describe the taxpayer's compliance behavior. They use variables known as economic factors, namely: income before tax, tax rate, the amount of opportunity to be examined and the magnitude of the penalty. The decision to report the SPT is a decision in uncertainty because not to report a full income does not automatically get a penalty. The Motivation Crowding Effect suggests that external interventions through monetary incentives or penalties may weaken, and in different identifiable conditions, strengthen intrinsic motivation (Frey \& Jegen, 2001). Crowding Motivation Theory tries to directly link between standard economic models and psychological theory by establishing a systematic interaction between extrinsic and intrinsic motivation. The effects of external interventions on intrinsic motivation have been linked to two psychological processes, i.e. (1) The selfdetermination Impaired is the ethics external intervention lowers their personal determination, intrinsic motivation will be replaced by extrinsic control; (2) Impaired self-esteem is ethics outside intervention brings the notion that individual motivation is not recognized, intrinsic motivation is effectively rejected. Individuals will feel their competence is not appreciated thereby lowering their efforts to do something. There are two processes that allow psychological conditions where the crowding-out effect will emerge 1) external interventions weaken intrinsic motivation if the affected individuals feel they are controlled. In this regard, both the Impaired self-determination and the Impaired self-esteem and individual react by reducing their intrinsic motivation in controlled activity; 2) External intervention strengthens the intrinsic motivation when the individual concerned considers it as supportive. In this regard, self-esteem is cultivated and individuals feel that they are given more freedom to act, thereby enlarging personal determination (Syamsuriana et al., 2019). According to Mardiasmo (2016), tax sanctions is a guarantee that the provisions of taxation legislation (tax norm) will be adhered to. Or can in other words taxation is a preventive tool (preventative) so that the taxpayer does not violate taxation norms. In taxation legislation known two kinds of sanctions, namely administrative sanctions and criminal sanctions.

There are various findings on the influence of Taxation sanctions. A number of studies for example Beck, Jon, \& Jung, (1991); Park \& Hyun, (2003) demonstrated positive influence on higher penalties on tax compliance but other research for example Alm, Bahl, \& Murray, (1990), Alm, Jackson, \& McKee, (1992) leads to opposite findings. The severity of such penalties can only prevent taxpayers from reporting their actual income due to the possibility of obtaining greater than likely loss (Slemrod, 2004). In addition, the impact of penalties also varies according to the taxpayer group. For example, the severity of criminal fraud penalties was found to be positively related to individual behavior (Alm et al., 1990). On the other hand, civil penalties seem to have a negative relationship with mandatory behaviors of individuals (Witte \& Woodbury, 1985).

Consciousness is an element in the human being to understand reality and how they act or behave against reality. Jatmiko (2006) outlines some forms of paying tax awareness that encourages taxpayers to pay taxes. First, the realization that tax is a form of participation in supporting the development of the country. By realizing this, taxpayers are willing to pay taxes because they feel unharmed from the tax-deductible. Secondly, the realization that delayed tax payments and tax reductions was detrimental to the country. Taxpayers pay tax for understanding that delayed tax payments and tax deductions affect a lack of financial resources that may result in the development of the country. Thirdly, the realization that taxes are set by law and can be imposed. Taxpayers will pay as the tax payment is realized to have a strong legal basis and is the absolute obligation of every citizen.

Jatmiko, (2006), Sumarso, (1998) stated that awareness of the low taxation of society is often one of the reasons why there are potential taxes that cannot be netted. Jatmiko (2006), Lerche (1980) also suggested that taxation awareness is often an obstacle in the issue of tax collection from the community. Taxation awareness is a conscious attitude to the tax function, a constellation of cognitive, effective and conscientious components, which interact in understanding, sensing and behaving to the meaning and function of the tax. Taxation awareness of logical consequences for taxpayers, namely the taxpayer's willingness to contribute funds to the implementation of taxation function, by means of paying the tax obligations in a timely and precise amount (Shiddiq, 2011). According to Rahmawati \& Qomariah (2006) in national Tax Symposium 4 Taxpayer awareness is a condition where the taxpayer knows, understands and executes the taxation provisions correctly and voluntarily. Taxpayers who are conscious and aware of the importance of tax contributions in development and welfare will have their own encouragement to be taxpayers who are conscious and obedient to taxes without any element of coercion from both taxation officers and themselves. 
McLeod, (2008) Explain that social norms (social norm) social norms constitute an unwritten regulation of how to behave, the rules used by a social or cultural group of values, beliefs, attitudes, and behaviors that can or may not be acceptable. The regulation may be written or publicly stated (explicit), or not written nor publicly stated (implicit). Failure to follow these rules would result in a number of possible penalties, one of which was excommunicated from the group ( Perkins \& Berkowitz, 1986). In social sciences, social norms are defined as an agreed and enforced attitude together, attitudes about what to do and what not to do in certain situations. Social norms are similar to the law, only less formal. The standards expected are not objectively recorded, and their enforcement is also informal, usually through social penalties from internal groups and communities. Social norms represent a group because they act as characteristics describing something that a group thinks, feels, and does.

This description illustrates that to form the norm, there must be a group describing the characteristics of the norm. The power of social norms in shaping behavior exists in the dynamics of social psychology that emerge in a group, such as the tendency of group members to see each other for guidance, affirmation, and approval, and also the pressure to achieve the uniformity produced by the group. The group may be a club, organization, community, social environment, or network, which can be either a formal or informal group, face-to-face or virtual. The most important thing is that members of the group consider themselves as peers, equal, similar in certain interests, and consider the opinions and behaviors of other group members relevant to themselves.

The social norms theory argues that individual behaviors are often influenced by perception of how other members in a group think and act (Berkowitz, 2004). The social norms approach was originally developed by Perkins \& Berkowitz (1986) In an analysis of the alcohol use patterns in students. In his studies they explained that most students considered their friends to provide support for the behavior of drinking alcohol, and they found that the assumption could predict how much one is drinking alcohol. Researchers have repeatedly found that perception of what most people do can influence a person to behave differently, even on behaviors unrelated to morale, such as choosing a product of Consumption (Venkatesan, 1966), or the behavior of looking toward the heavens (Milgram, Bickman, \& Berkowitz, 1969). The injunctive social norm refers to the rule or conviction of what behavior is morally accepted and rejected. Unlike the descriptive norm which is based on the behavior already emerging and has been done, the norm is injunctive based on what should be done. This means that the injunctive norms are more instrumental in the rules and social sanctions in general rather than through common behaviors that arise. The intent of the two norms above is quite similar between the two because acceptable behavior is a behavior usually done by many people. However, the two different norms are conceptually and motivated, so it is important to understand precisely that they can distinguish between them, especially in situations where both norms are raised at the same time (Cialdini, Reno, Kallgren, 1991). Research suggests that activating social norms about littering can substantially reduce or improve one's decision to littering. Such a situation activates a person's norm of belief, then generates a feeling of shame because it violates the social norms, and the feeling of guilt (guilt) because it violates the personal norms. (Cialdini, 2003; Cialdini et al., 2005).

According to Wexley \& Yukl (1984) motivation is the gift of motive or the moon, can also be interpreted as a matter or condition of motive. While according to Mitchell (in Winardi, 2002) The motivation represents the psychological processes, which cause the onset, the purpose, and the persistence of voluntary activities (voluntary) that are directed to a particular destination. While according to Winardi, (2002) motivation is a number of processes, which are internal, or external to an individual, which leads to an attitude of enthusiasm and persistence, in terms of carrying out certain activities. Morgan (in Soemanto, 1987) suggests that the motivation is related to three things as well as aspects of motivation. These three are 1) circumstances that promote motivating states, behaviors that are encouraged by the situation (motivated behavior), and the purpose of the behavior (goals or ends of such behavior).) Motivation as a change of energy within a person that is characterized by effective encouragement and the reactions to achieving goals. Motivation is a complex problem in the organization, because the needs and desires of each member of the organization differ from one another. This is different because each member of an organization is uniquely biologically and psychologically, and develops on the basis of different learning processes (Suprihanto et al., 2003). Soemanto (1987) generally defines motivation as an energy change characterized by effective encouragement and the reaction of achievement of objectives. Because the human behavior is always aimed, we can conclude that the change of 
energy that gives power to my behavior reaches the goal, has occurred in a person. From the above explanation it can be concluded that motivation is a number of psychological processes, which lead to the onset, the purpose, and the persistence of voluntary activities (voluntary) directed to a specific goal, whether internal, or external to an individual, which leads to an attitude of enthusiasm and persistence.

\section{Research Method}

The approach used in this study is quantitative research. That is, the research method that emphasizes on objective phenomena-phenomenon and in use to examine the population or certain samples, sampling techniques are generally done randomly, data collection using research instruments, data analysis is quantitative/statistic with the aim to test the hypothesized hypothesis. The result of the research is generalization and prediction based on the results of the measurements that the truth of the research results are supported by the validity of the way/tools used. This research was held in KPP Selatan Makassar. The variables studied were causality relationships between the variables of taxation sanctions, taxpayer awareness, and social norms. To get the information needed in this study, the authors use several techniques: questionnaire that is the technique of data collection through a list of such written questions to the respondent with the intent to obtain accurate and valid data. The population in this research is the taxpayers selected randomly in South Makassar primary GROUP, as much as 79 taxpayers. The data analysis methods used in this study are as follows: Descriptive analysis is used to analyze the influence of the variable's impact on dependent variables. Multiple regression analyses are methods used to answer the relationship between each free variable and a bound variable.

\section{Result and Discussion}

\section{Result}

Based on table 1, It is revealed that the constant value is $B o=0622$, the variable Taxation sanctions of 0.151 , the variables of the taxpayer awareness, 0281 , and social norms 0.307 so that the regression equation obtained is:

$$
\mathrm{Y}=\mathbf{0 . 6 2 2}+\mathbf{0 , 1 5 1} \mathrm{X} 1+0,281 \mathrm{X} 2+0,307
$$

The constant value is $\mathrm{Bo}=0.622$, meaning that, when the tax sanctions, taxpayer awareness and social norms is not subjected to change, the tax is motivated to fulfill its taxation obligations of 0622, or 62.2. The variable coefficient of taxation sanctions amounted to 0.151 , this means that with a well-executed taxation sanctions will increase the taxpayer's motivation, where any increase in the taxation sanctions will increase the taxpayer's motivation, assuming the variables $\mathrm{X} 2$ and $\mathrm{X} 3$ have a constant value. The Taxpayer awareness variable coefficient (X2) amounted to 0281, this means that a high taxpayer awareness will increase the taxpayer's motivation, whereby any increase in tax-related awareness will increase the motivation to encourage taxpayers in fulfilling their exposure obligations, assuming the $\mathrm{X} 1$ variable and $\mathrm{X} 3$ variables are constant value. The variable coefficient of social norms is 0307 , this means that a good social norms factor will raise the taxpayer's motivation, which each increase will raise the taxpayer's motivation, assuming the X1 variable and the variable $\mathrm{X} 2$ are of constant value. The magnitude of the value of multiple correlation coefficient $(\mathrm{R})$ is 0670, this shows that the magnitude of the relationship between the independent X1, X2, and X3 variables, with the dependent variable (Y) is the motivation to pay tax of 0670 or 67.0 and this indicates that the tax sanctions (X1) variable, taxpayer awareness (X2), and social norms (X3) jointly have a relationship to the tax payer's motivation to pay taxes at Makassar's primary tax office. The magnitude of the value of coefficient of determination (R2) is 0449 , it shows that the magnitude of the influence of the independent variable (X) to the taxpayer's motivation of 0449 or (44.9) and the remainder of 0551 or 55.1 is influenced by other factors or variables not included in this model of research. 
Table 1 Result

Coefficientsa

\begin{tabular}{|c|c|c|c|c|c|c|}
\hline & \multirow{3}{*}{ Model } & \multirow{2}{*}{\multicolumn{2}{|c|}{ Unstandardized Coefficients }} & \multirow{3}{*}{$\begin{array}{c}\begin{array}{c}\text { Standardized } \\
\text { Coefficients }\end{array} \\
\text { Beta }\end{array}$} & \multirow{3}{*}{$\mathbf{t}$} & \multirow{3}{*}{ Sig. } \\
\hline & & & & & & \\
\hline & & $\mathrm{B}$ & Std. Error & & & \\
\hline \multirow{4}{*}{1} & (Constant) & .622 & .571 & & 2.137 & .036 \\
\hline & Taxation sanctions & .151 & .161 & .121 & 2.403 & .035 \\
\hline & Taxpayer awareness & .281 & .088 & .316 & 3.204 & .002 \\
\hline & Social norms & .307 & .130 & .302 & 2.363 & .021 \\
\hline & $\begin{array}{l}R=0,670 \\
R_{2}=0,449\end{array}$ & \multicolumn{5}{|c|}{$\begin{aligned} \text { F Count } & =10.470 \\
\text { Sig } & =0,000\end{aligned}$} \\
\hline
\end{tabular}

Simultaneous testing

This test is intended to know how the Independent (free) variable that is comprised of taxation sanctions of taxpayer Awareness and the simultaneous social norms variables (together) have an effect on taxpayer motivation to fulfill its tax obligations. By acquire F-count $=10,470>\mathrm{f}$ tabel $=2.71(\mathrm{df} 1=3, \mathrm{DF} 2=76)$ and has a significance rate of 0.000 . Because the probability of 0.000 is much smaller than 0.05 , it can be said that the regression model that has been used this can raise the motivation of taxpayers in fulfilling its tax obligations in the KPP primary office in South Makassar.

Partial test

(H1) The Research results that test the influence of taxation sanctions on the taxpayer motivation gained judging by the calculated $\mathrm{t}$ value $=2,403>\mathrm{t}$ table $=1,665$ with significance rate of 0.035 , smaller when compared to a significant rate of $\alpha=5 \%$. These results indicate that in the calculation of the taxation sanctions statistics affect the taxpayer's motivation. Thus the first hypothesis received

(H2) The Research results that test the influence of taxpayer awareness on WP Motivation obtained the value $t$ count $=3,204>\mathrm{t}$-table $=1,665$ with significance rate of 0.002 , smaller compared to $\alpha$ level $=5 \%$. These results indicate that in the calculation of the taxpayer awareness statistics affect the taxpayer's motivation to fulfill its tax obligations. Thus the second hypothesis was received.

(H3) The Research results that test the influence of social norms on the WP motivation acquired the count $t$ value $=2,363>\mathrm{t}$-table $=1,665$ with significance rate of 0.021 , smaller when compared to $\alpha$ levels $=5 \%$. These results suggest that the statistical calculations of social norms affect the taxpayer motivation. Thus the third hypothesis was received.

\section{Discussion}

The influence of taxation sanctions on motivation taxpayers

Based on the results of the study, it was found that taxation sanctions positively and significantly affect the taxpayer's motivation to fulfill its tax obligations. Based on the results of this research then, this research is supported by the theory of withholding tax is conducted by the approach of "Benefit Approach" or benefits approach. This approach is fundamental to the philosophical basis that allows the country to do tax-voting with the system can be enforced in the sense that the state has authority with the force of compulsion. This is because the tax collection is a step in the law enforcement. This applies to taxpayers who do not adhere to their tax obligations. This is where tax sanctions are. So tax sanctions are aimed at the taxpayer who complies with the obligation of his exposure.

The benefit of this approach bases a philosophy: Because the country creates benefits enjoyed by all citizens, the state is empowered to collect taxes from the people in a manner that can be imposed, and this is related to the enforcement of tax office. Research findings are also supported with rational expectation theory. In this theory, the taxpayer will only obey the obligation of his trade if they are to be examined and if the high tax fines (Allingham \& Sandmo, 1972). However, the examination policy and the tax fines sometimes have contradictory effects to what is expected (Holler et al., 2008). The form of benefits that can be enjoyed by citizens is welfare, General Service, legal protection, freedom, the use of public facilities.

The results of this research in line with the research of Raihana Mohdali et al, (2014) the impact of threat of 
punishment on tax compliance and non-compliance attitudes in Malaysia. The study found that the threat of punishment was influential for taxpayer compliance. In another study, Alm \& Finlay (2013), through his research expanding the Theory of Tax Compliance from Individual to Group Motivations, found that with the punishment, the tax obligatory would be motivated in fulfilling its tax obligations. The results of this study were also supported by the research of Chandler Alm \& McClellan, (2012). Tax Compliance from the firmware's Perspective. (International Review for Social Science), which finds that individual intrinsic motivation arises from external influences, one of which is a threat to taxpayers.

In another study, according to Sri Putri Tita Mutia (2014) in his research on the influence of taxation sanctions, taxation awareness, facial services and the level of understanding of personal taxpayers ' tax compliance (empirical studies on taxpayers enrolled in the personal person registered in KPP Pratama Padang) found that the tracking sanctions were positive and significant to taxpayer compliance. In the results of another study (Siti Kurnia, 2010). Found that taxpayers will be obedient because they think of severe sanctions due to illegal actions in attempts to smuggle taxes

Taxpayer's influence on taxpayers ' awareness

Based on the results of the study, it was found that taxpayers ' awareness positively and significantly affect the taxpayer's motivation to fulfill its taxation obligations. With the results of this research, tax awareness is a taxpayer behavior in the form of views or perceptions involving confidence, knowledge and reasoning as well as a tendency to act in accordance with the stimulus given by the system and the prevailing taxation provisions. From the respondent's response to the taxpayer awareness variable, it was found that, overall, the respondent's response was categorized into several quadrants i.e. views or perceptions, taxpayer knowledge, taxpayer confidence, taxpayer motives, and taxpayer reasoning against external dynamics (Alm \& Vazquez, 2003).

Taxpayers are obedient, because of awareness, and awareness arises several quadrants, can be through the knowledge of his exposure, or his belief in the benefit approach. This is reflected for example in the question: Do you understand that by paying taxes means you are participating in the nation and state development. The basis of this answer is the integration or combination of several quadrants of confidence, knowledge, and taxpayer perception. So there are simultaneous involvement between attitudes, behaviors, and beliefs, so that there comes a motive of acting, there is a push of ethical behavior that is the basis of motivation, then obedience and the adversary becomes the fulfillment of obligations.

As seen in the indicator of the tax awareness of the face used in this research is the indicator in the measure of taxpayer awareness level: awareness of tax function, awareness to pay tax not due to compulsion, awareness of the benefits of tax paid and awareness that the tax is governed by the taxpayer compliance law. Further we can analysis in the question: Do you understand that the State in distress in financing the expenditure of the State and the people. The answer to this question certainly has the charge of some of the quadrants mentioned above. The mission is the sense of empathy, nationalism, and sensitivity to the phenomenon that occurs in the environment of observation and knowledge.

The results of this research are supported by the findings of Puri (2014) stating that with the knowledge of taxation by adequate society, it will be easy for taxpayers to comply with taxation regulations, the level of compliance will be better if the taxpayer already has awareness. Taxpayers are also influenced by many factors, such as knowledge, labour sanctions, good service, public confidence, perceived benefits, and fairness. This is where unconditionally voluntary of compliance will appear.

The influence of social norms on taxpayer motivation

Based on the results of this study, it was discovered that social norms have a positive and significant effect on the taxpayer's motivation to fulfill its taxation obligations. Both partial and simultaneous testing, this variable remains in contact with a significant and substantial, so that hypothesized (H3) is acceptable. The results of this study were supported by the theory or view of Janne Chung Viswanath Umashanker Trivedi, (2003) in her research The Effect of Friendly persuasion and Gender on Tax Compliance Behavior. Trivedi suggests that a friendly persuasion, unlike preventive measures such as tax checks and unreported tax sanctions. Perhaps the government or tax Fischus need to Circumcise and analyze how the role of social norms, in order to understand the details of abstract things related to the taxpayer's conduct. The results of this research are also in line with 
the theories and research of Cialdini \& Trost (1998), which in its study, found that personal norms became very significant with taxpayer compliance, and the motivation of taxpayers in paying tax receipts. It may be obligatory to be exhausted by threats, and letters of reprimand, or other forms of business that tax Fischus do. Social norms theory also includes the role of Indigenous local or the local wisdom, which contributes to the theory of social norms expressed by Cialdini. If associated with a taxpayer's motivation then in the study of compliance and intrinsic motivation such as, conducted by (Slemrod et al., 2001; Blumenthal et al., 2001; Kleven et al. 2011; Castro and Scartascini 2015; Pomeranz 2015; Dwenger et al., 2016; Boyer et al., 2016; Hallsworth et al., 2017; Bott et al., 2017; Drago et al. 2017), which in general concluded that the anatomy of taxpayers ' behavior is related to social norms personally in the context of different moral behaviors, in fulfilling taxation obligations. Luttmer and Singhal (2014) Doerrenberg \& Peichl (2017) Also "argue that moral tax is indeed an important component of tax compliance decisions, although law enforcement is the primary driver of compliance." Furthermore Redae (2016), Togler (2013) found that taxpayers generally pay their taxes, because they are motivated by external and internal factors. Where external factors are contained therein is the social norm.

Behavioral studies related to social norms, such as those of Wibowo (2018), find that taxpayers with high levels of religious obedience, high spiritual intelligence, have good awareness and compliance in terms of formation of Intrinsic motivations that naturally exempt taxpayers from various forms of socialization, rebuke, and even threats, for their tax obligations. Based on the results of this research, that with a regression coefficient value of 30.7 proves that social norms have a strong influence over taxpayer sanctions and awareness. The results of this research in line with Wibowo's research (2018), which found that with high social norms, will form a taxpayer's motivation to fulfill its tax obligations.

\section{Conclusions}

The results showed taxpayer sanctions and tax awareness and norma sosial influence positive and significant to the motivation of taxpayer in fulfilling its taxation obligations in KPP Pratama Makassar Selatan. The results of this study suggest that taxation sanctions need to be enforced to increase taxpayer awareness. Tax Fiscus may use a more persuasive approach in the face of taxpayers. It is in accordance with the philosophy that the government needs eggs instead of chickens. Therefore, do not turn off the chicken. Taxpayer awareness is expected to arise from taxpayers, although the government is always striving to raise taxpayer awareness. This needs to be affirmed so that the Community really understands the importance of tax for national development financing, and the Indonesian people's welfare. It is advised that the government is more aggressive in instilling the values of consciousness as early as possible for all walks of life, especially the young generation so that they have a well-directed taxation knowledge that gives birth to voluntary of compliance. Social norms also have a very important and strategic role in dealing with taxpayers. Advised in conducting counseling and examination and supervision in order to pay attention to factors of social norms such as local culture, local customs, because in this way then obligatory awareness will easily form voluntarily

\section{References}

Allingham, M. G., \& Sandmo, A. (1972). Income tax evasion: A theoretical analysis. Journal of public economics, 1(3-4), 323-338.

Alm, J., Bahl, R., \& Murray, M. N. (1990). Tax structure and tax compliance. The Review of Economics and Statistics, 603-613.

Alm, J., Jackson, B. R., \& McKee, M. (1992). Estimating the determinants of taxpayer compliance with experimental data. National Tax Journal, 107-114.

Alm, J., \& Martinez-Vazquez, J. (2003). Institutions, paradigms, and tax evasion in developing and transition countries.

Alm, J. (2012). Measuring, explaining, and controlling tax evasion: lessons from theory, experiments, and field studies. International tax and public finance, 19(1), 54-77. 
Alm, J., \& McClellan, C. (2012). Tax morale and tax compliance from the firm's perspective. Kyklos, 65(1), 1-17. Alm, J., \& Finlay, K. (2013). Who benefits from tax evasion?. Economic Analysis and Policy, 43(2), 139-154.

Beck, P. J., Davis, J. S., \& Jung, W. O. (1991). Experimental evidence on taxpayer reporting under uncertainty. Accounting Review, 535-558.

Becker, G. S. (1968). Crime and punishment: An economic approach. In The economic dimensions of crime (pp. 13-68). Palgrave Macmillan, London.

Berkowitz, A. D. (2004). The social norms approach: Theory, research, and annotated bibliography.

Bott, K. M., Cappelen, A. W., Sørensen, E. Ø., \& Tungodden, B. (2019). You've got mail: A randomized field experiment on tax evasion. Management Science.

Boyer, P. C., Dwenger, N., \& Rincke, J. (2016). Do norms on contribution behavior affect intrinsic motivation? field-experimental evidence from germany. Journal of Public Economics, 144, 140-153.

Cahyonowati, Nur; Ratmono, Dwi \& Faisal. (2012). Peranan Etika, Pemeriksaan, Dan Denda Pajak Untuk Meningkatkan Kepatuhan Wajib Pajak Orang Pribadi. Journal Akuntansi dan Keuangan Indonesia, Volume 9, no. 2.

Castro, L., \& Scartascini, C. (2015). Tax compliance and enforcement in the pampas evidence from a field experiment. Journal of Economic Behavior \& Organization, 116, 65-82.

Chung, J., \& Trivedi, V. U. (2003). The effect of friendly persuasion and gender on tax comliance behavior. Journal of Business Ethics, 47(2), 133-145.

Cialdini, R. B., Kallgren, C. A., \& Reno, R. R. (1991). A focus theory of normative conduct: A theoretical refinement and reevaluation of the role of norms in human behavior. In Advances in experimental social psychology (Vol. 24, pp. 201-234). Academic Press.

Drago, D., Di Tommaso, C., \& Thornton, J. (2017). What determines bank CDS spreads? Evidence from European and US banks. Finance Research Letters, 22, 140-145.

Doerrenberg, P., Peichl, A., \& Siegloch, S. (2017). The elasticity of taxable income in the presence of deduction possibilities. Journal of Public Economics, 151, 41-55.

Dwenger, N., Kleven, H., Rasul, I., \& Rincke, J. (2016). Extrinsic and intrinsic motivations for tax compliance: Evidence from a field experiment in Germany. American Economic Journal: Economic Policy, 8(3), 203-32.

Frey, B. S., \& Jegen, R. (2001). Motivation crowding theory. Journal of economic surveys, 15(5), 589-611.

Hallsworth, M., List, J. A., Metcalfe, R. D., \& Vlaev, I. (2017). The behavioralist as tax collector: Using natural field experiments to enhance tax compliance. Journal of public economics, 148, 14-31.

Hanno, D. M., \& Violette, G. R. (1996). An analysis of moral and social influences in tax compliance. Behavioral Research in Accounting, 8, 57-75.

Holler, M., Hoelzl, E., Kirchler, E., Leder, S., \& Mannetti, L. (2008). Framing of information on the use of public finances, regulatory fit of recipients and tax compliance. Journal of Economic Psychology, 29(4), 597-611.

Jackson, B. R., \& Milliron, V. C. (1986). Tax compliance research: Findings, problems, and prospects. Journal of accounting literature, 5(1), 125-165.

Kleven, H. J., Knudsen, M. B., Kreiner, C. T., Pedersen, S., \& Saez, E. (2011). Unwilling or unable to cheat? Evidence from a tax audit experiment in Denmark. Econometrica, 79(3), 651-692.

Kohlberg, L. (1969). Stages and Sequences: The Cognitive Development Approach to Socialization. dalam D. Goslin (ed.). Handbook of Socialization Theory and Research. Chicago: Rand McNally.

Lerche, D. (1980). Efficiency of taxation in Indonesia. Bulletin of Indonesian Economic Studies, 16(1), 34-51.

Luttmer, E. F., \& Singhal, M. (2014). Tax morale. Journal of economic perspectives, 28(4), 149-68.

Milgram, S., Bickman, L., \& Berkowitz, L. (1969). Note on the drawing power of crowds of different size. Journal of personality and social psychology, 13(2), 79.

Mutia, S. P. T. (2014). Pengaruh Sanksi Perpajakan, Kesadaran Perpajakan, Pelayanan Fiskus, Dan Tingkat Pemahaman Terhadap Kepatuhan Wajib Pajak Orang Pribadi (Studi Empiris pada Wajib Pajak Orang Pribadi yang terdaftar di KPP Pratama Padang). Jurnal Akuntansi, 2(1).

Mohdali, R., Isa, K., \& Yusoff, S. H. (2014). The impact of threat of punishment on tax compliance and noncompliance attitudes in Malaysia. Procedia-Social and Behavioral Sciences, 164, 291-297.

Park, C. G., \& Hyun, J. K. (2003). Examining the determinants of tax compliance by experimental data: A case of Korea. Journal of Policy Modeling, 25(8), 673-684.

Perkins, H. W., \& Berkowitz, A. D. (1986). Perceiving the Community Norms of Alcohol Use among Students: Some Research Implications for Campus Alcohol Education Programming*. Substance Use \& Misuse, 21(910), 961-976. 
Pomeranz, D. (2015). No taxation without information: Deterrence and self-enforcement in the value added tax. American Economic Review, 105(8), 2539-69.

Puri, K. A. (2014). Pengaruh Kesadaran Wajib Pajak, Pelayanan Fiskus, Dan Sanksi Pajak Terhadap Kepatuhan Wajib Pajak Orang Pribadi Yang Melakukan Kegiatan Usaha Dan Pekerjaan Bebas (Studi Kasus pada KPP Pratama Surakarta) (Doctoral dissertation, Universitas Muhammadiyah Surakarta).

Rahmawati, S. Y., \& Qomariyah, N. (2006). Pengaruh Informasi Asimetri Terhadap Praktik Manajemen Laba Pada Perusahaan Perbankan Publik Yang Terdaftar di Bursa Efek Jakarta. Prosiding Simposium Nasional Akuntansi.

Redae, R. B., \& Sekhon, S. (2016). Taxpayers' knowledge and tax compliance behavior in Ethiopia: A study of Tigray State. International Journal of Management and Commerce Innovations, 3(2), 1090-1102.

Sandmo, A. (2005). The theory of tax evasion: A retrospective view. National tax journal, 643-663.

Slemrod, J., Blumenthal, M., \& Christian, C. (2001). Taxpayer response to an increased probability of audit: evidence from a controlled experiment in Minnesota. Journal of public economics, 79(3), 455-483.

Slemrod, J. (2004). The economics of corporate tax selfishness (No. w10858). National bureau of economic research.

Soemarso, S. R. (1998). Dampak Reformasi Perpajakan 1984 Terhadap Efisiensi Sistem Perpajakan Indonesia. Economics and Finance in Indonesia, 46, 333-366.

Suhardito, Bambang dan Sudibyo, Bambang, 1999, Pengaruh Faktor-faktor yang Melekat pada Wajib Pajak terhadap Keberhasilan Penerimaan Pajak Bumi dan Bangiman, Simposium Nasional Akuntansi, SNA 11:1-14.

Syamsuriana, N., Nasaruddin, F., Suun, M., \& Ahmad, H. (2019). Dampak Perilaku Altruisme, Moral Reasoning dan Kecerdasan Emosional Terhadap Kualitas Audit. ATESTASI: Jurnal Ilmiah Akuntansi, 2(2), 98-110.

Tiraada, T. A. (2013). Kesadaran perpajakan, sanksi pajak, sikap fiskus terhadap kepatuhan wpop di kabupaten minahasa selatan. Jurnal EMBA: Jurnal Riset Ekonomi, Manajemen, Bisnis dan Akuntansi, 1(3).

Torgler, B., Schaffner, M., \& Macintyre, A. (2007). Tax compliance, tax morale and governance quality (No. 200717). CREMA Working Paper.

Torgler, B. (2013). A field experiment in moral suasion and tax compliance focusing on underdeclaration and overdeduction. FinanzArchiv/Public Finance Analysis, 393-411.

Venkatesan, M. (1966). Experimental study of consumer behavior conformity and independence. Journal of marketing research, 3(4), 384-387.

Wexley, K. N., \& Yukl, G. A. (1984). Organizational behavior and personnel psychology. Richard D. Irwin.

Wibowo, W. (2018). Joint Audit Ditjen Pajak dan Ditjen Bea dan Cukai: Analisis Faktor-Faktor Pemampu Kerja Sama dan Pertukaran Informasi. Universitas Gadjahmada.

Witte, A. D., \& Woodbury, D. F. (1985). The effect of tax laws and tax administration on tax compliance: The case of the US individual income tax. National Tax Journal, 1-13.

Winardi, J. (2002). Motivasi dan pemotivasian dalam manajemen. Jakarta: PT. Raja Grafindo Persada. 